\title{
Effects of the Educational Games on Primary School Students' Speaking Skills and Speaking Anxiety*
}

\section{Eğitsel Oyunların İlkokul Öğrencilerinin Konuşma Becerilerine ve Konuşma Kaygılarına Etkisi}

\author{
Huri ASAN $^{* *}$ (i) Zuhal ÇELİKTÜRK-SEZGİN*
}

Received: 22 March 2020

Research Article

Accepted: 31 August 2020

ABSTRACT: The aim of this study is to determine the effects of educational games used in lesson Turkish on primary school fourth-grade students' impromptu speaking skills and speaking anxiety. In the research, one of the semi-experimental models, pretest and posttest nonequivalent groups design was used. The study group consisted of 28 students in 4-A and 4-B classes in a public school in the city center of Burdur in the first semester of 2018-2019 academic year. In the experimental group, Turkish lessons were taught and supported by educational games for six weeks. In the control group, it was processed in accordance with the basic teaching-learning approaches in the Turkish Curriculum. According to the results of the study, it was concluded that educational games positively affected the three-dimensional speaking order and style of speech, including the use of voice, which are composed of audibility and meaningfulness dimensions, topic and thought transfer, refinement, and use of time. It was concluded that educational games did not affect students' speaking anxiety. The fact that the state of anxiety is not affected by this six-week practice of educational games may be due to the short implementation period. Therefore, a similar study can be repeated with a wider sample group with a longer application period.

Keywords: Educational game, speaking skill, speaking anxiety, primary school.

ÖZ: Bu araştırmanın amacı, Türkçe dersinde kullanılan eğitsel oyunların ilkokul 4. sınıf öğrencilerinin hazırlıksız konuşma becerilerine ve konuşma kaygılarına etkisini belirlemektir. Araştırmada yarı deneme modellerinden ön testson test eşitlenmemiş kontrol gruplu model kullanılmıştır. Araştırmanın çalışma grubunu, 2018-2019 eğitim-öğretim yılı birinci döneminde Burdur il merkezindeki bir devlet okulundaki 4-A ve 4-B sınıflarındaki 28 öğrenci oluşturmaktadır. Deney grubunda Türkçe dersleri altı hafta boyunca araştırmacı tarafindan eğitsel oyunlarla desteklenerek işlenmiştir. Kontrol grubunda ise Türkçe Dersi Öğretim Programındaki öğrenme-öğretme yaklaşımlarına uygun olarak işlenmiştir. Araştırma sonuçlarına göre; eğitsel oyunların, öğrencilerin konuşma sırasında işitilebilirlik ve anlamlılık boyutlarından oluşan ses kullanma becerilerini, konu ve düşünce aktarımı, ayrıntılandırma ve zaman kullanımı olmak üzere üç boyuttan oluşan konuşma düzenini ve üslubunu olumlu yönde etkilediği sonucuna ulaşılmıştır. Eğitsel oyunların öğrencilerin konuşma kaygılarını etkilemediği sonucuna ulaşılmıştır. Kaygı durumunun, eğitsel oyunlardan oluşan bu altı haftalık uygulamadan etkilenmemesi, uygulama süresinin kısa olması ile açıklanabilir. Bu yüzden benzer bir çalışma daha geniş bir örneklem grubu ile daha uzun bir uygulama süreci ile tekrarlanabilir.

Anahtar kelimeler: Eğitsel oyun, konuşma becerisi, konuşma kaygısı, ilkokul.

\footnotetext{
* This article is derived from Huri Asan's master's thesis entitled "Effect of educational games on speech skills and speech anxiety of primary school fourth grade students", conducted under the supervision of Zuhal Çeliktürk Sezgin. ** Corresponding Author: Teacher, Milli Eğitim Bakanlığı, Burdur, Turkey, yilas_ogret@hotmail.com, https://orcid.org/0000-0001-5042-0968

*** Asst. Prof. Dr, Burdur Mehmet Akif Ersoy Üniversitesi, Burdur, Turkey, zuhalcelikturk@mehmetakif.edu.tr, https://orcid.org/0000-0001-7015-8426
}

\section{Citation Information}

Asan, H., \& Çeliktürk-Sezgin, Z. (2020). Effects of the educational games on primary school students' speaking skills and speaking anxiety, Kuramsal Eğitimbilim Dergisi [Journal of Theoretical Educational Science], 13(4), 685700 . 
Language skills have some subcomponents. For instance, receptive skills include reading and listening. Expressive skills are consisted of speaking and writing. In order to improve the language skills among children, it is necessary to give importance to all these skill domains. Improving only some of these language skills will be insufficient for comprehensive language development (Ünalan, 2001). Speaking can be seen as an important skill among other language skills (listening, reading and writing), because knowing a language is defined as speaking this language (Ur, 1996). Speaking can be defined as developing verbal expressions produced to convey meaning (Bailey, 2005). Since almost everyone knows how to speak, speaking education is seen as a negligible skill. However, it is very important for students to speak effectively and confidently in order to realize most of the basic skills (Bygate, 1987).

Speaking can be classified as planned and unplanned (impromptu) speaking depending on whether the speaker has plans for the speech or not. Planned speaking is predetermined and its aim, topic, place and date are determined before the speaking occurs in a planned (Yüceer, 2014). Impromptu speaking refers speaking that an individual makes in her daily life, in different environments, without any preparation (Sargin, 2006). There are some cognitive, affective and physical elements of speaking. Organizing ideas constitutes the affective elements such as cognitive element, vocalization physical element, attitude towards speech, self-efficacy, motivation, anxiety.

Anxiety studies generally focus on math anxiety, writing anxiety, reading anxiety, exam anxiety, writing and speaking anxiety in second a language (Cheng, 2004; Çeliktürk \& Yamaç, 2015; Daly \& Miller, 1975; Pekrun et al., 2004; Wigfield \& Eccles, 1989; Wigfield \& Meece, 1988; Woodrow, 2006). Anxiety is a negative condition that affects individuals emotionally and physically, and that has negative reflections on learning (Çeliktürk \& Yamaç, 2015, p. 99). Speaking anxiety directly affects the success in speaking. Speaking anxiety may occur before, during or after the speaking. Speaking anxiety is one of the anxiety types that usually occurs when someone is speaking in front of the community or during dialogue with people and that is manifested by some physical symptoms such as sadness, anger, fear, sweating, and increased heartbeat (Demir \& Melanlıŏlu, 2014; Keşaplı \& Çifci, 2017). In their study, Topçuoğlu Ünal and Degeç (2012) identified the major problems of students in speaking activities as follows; embarrassment, excitement, insufficient word treasure, local dialect. Accordingly, these problems made students feel embarrassed and withdrawn. Another finding of this research indicates that academic achievements of the students were affected negatively in consequence of the problems faced by the students.

In order for speaking education to be effective, a well-programmed education and training process and an appropriate education and training environment where the barriers to speaking are eliminated are needed. Games have been more employed in the education and training process in recent years, and through games, the permanent and meaningful learning is targeted. According to Demirel (2011), Educational game technique, provides students with the opportunity to consolidate and repeat information in a comfortable environment. It is thought that games that carry each individual to a comfortable and natural learning environment will also reduce the speaking anxiety. There are some studies in the literature examining the effect of educational games on speaking skills (Dewi, Kultsum, \& Armadi, 2017; Gedik, 2012). However, at the 
primary school level, no research investigating the effects of educational games on speaking skills has been encountered. Similarly, no study that focuses on the effect of educational games on speaking anxiety has been found.

Some findings of the studies on the speaking skill, anxiety and educational games are given as follows: In the study on the evaluation of the speaking skills of primary school students carried out by Sargin (2006), it was observed that the students did not use proverbs and idioms at the expected level, frequently repeat words or sentences, did not go beyond the topic at hand and just reflected the main idea. In the study examining 7th grade students' impromptu speaking skills by Yeşiltepe Sağlam (2010), it was concluded that students' success levels in impromptu speaking were quite low. In the study conducted by Yüceer (2014), a meaningful relationship was found between the impromptu speaking skill level of preservice Turkish language teachers and their participation in theater and drama activities. In the study of Emiroğlu (2015), examining the number of words used by students from different educational levels, more specifically from primary school to university, the number of words used was found to increase from primary school to university. In the study of Sevim and Gedik (2014) examining speaking anxiety of high school students in terms of various variables, a significant difference was found between gender and attitude variables towards the lesson and speaking anxiety. In the study conducted by Tüzemen (2016), it was concluded that academic contradiction technique was more effective than the activities carried out within the framework of the Turkish Teaching Program in having the positive change of attitudes of students towards Turkish lesson, development of speaking skills and reduction of speaking anxiety.

Gedik (2012) analysed the effects of the educational games on 6th grade students' basic language skills and concluded that educational games are much more functional in contrast to the existing teaching methods in terms of long-lasting learning and improving the basic language skills. Varan (2017) analysed the effects of the educational games on the expansion of the fourth-grade elementary school students' lexical and found that vocabulary teaching through educational games improves their mental lexicons. Dewi et al. (2017) examined the effects of the communicative games on speaking skills of junior high students in Jakarta, Indonesia. They concluded that such games have positive effects on the fluency of students' speaking.

It is thought that pre-designed teaching activities may have an effect on reducing or eliminating speaking anxiety and improving speaking skills in students. Accordingly, this study was carried out to examine the speaking skills of primary school fourth-grade students and the effects of educational games on speaking anxiety. It can be said that the Turkish course is a course, in which students gain and improve their basic language skills. Including educational games in this course is also expected to add variety and richness to Turkish lesson in terms of method and activity. At the same time, the effects of educational games on the speaking skills will be tested. Anxiety, which emerged as a negative predictor in the academic and affective development of children, will be examined in this research whether educational games will have any effect on reducing speaking anxiety. In this context, the research problem/question of the current research is as follows; "What is the effect of educational games on the impromptu speaking skills and speaking anxiety of primary school fourth-grade students?" 
Based on this general research question the study attempts to answer the following sub-research questions:

1. What is the effect of educational games on the impromptu speaking skills of primary school fourth-grade students?

a. Is there a significant difference between pre- and posttest impromptu speaking success in terms of sound scores of experiment and control groups?

b. Is there a significant difference between pre- and posttest impromptu speaking success in terms of pronunciation scores of experiment and control groups?

c. Is there a significant difference between pre- and posttest impromptu speaking success in terms of speaking order scores of experiment and control groups?

d. Is there a significant difference between pre- and posttest impromptu speaking success in terms of vocabulary scores of experiment and control groups?

e. Is there a significant difference between pre- and posttest impromptu speaking success in terms of style scores of experiment and control groups?

f. Is there a significant difference between pre- and posttest impromptu speaking success in terms of body language scores of experiment and control groups?

2. What is the effect of educational games on speaking anxiety of elementary school fourth-grade students?

a. Is there a significant difference between the pre- and posttest speaking anxiety scores of the experiment and control groups?

\section{Method}

\section{Design of the Study}

This study is designed as a pretest and posttest nonequivalent groups design which is part of semi-experimental research designs. Semi-experimental research designs are used where some variables cannot be taken under control or cannot be provided in experimental research designs (Karasar, 2007, p. 99). The difference of the pretest and posttest nonequivalent groups design, which is the model of this research, from the experimental research models is that the groups could not be determined objectively before the application. This model is preferred especially in cases where it is difficult to select individuals impartially in educational research (Baştürk, 2011).

\section{Participants}

The participants of the study are fourth-grade primary students attending a public school in Burdur during the school year of 2018-2019 fall semester. More specifically, eight male and seven female students from the 4-A class and four male and nine female students from the 4-B class participated in the study. They were chosen using the convenience sampling which is among the non-random sampling techniques. The experiment group included fifteen students from the 4-A class, whereas the control group, thirteen students from the 4-B class. The students in both groups have similar 
characteristics (e.g gender, socioeconomic structure, academic achievement level). Before the study, the required permissions were provided. In addition, the research was carried out in accordance with ethical principles.

\section{Data Collection Tools}

The data of the study were collected through the use of the following tools: Personal Information Forms, Impromptu Speaking Topics, Turkish Lesson Plans, the Impromptu Achievement Rubric and Speaking Anxiety Scale.

Personal information form: This form was developed by the authors to have information about the demographical characteristics of the participants. It was also reviewed by the field experts before developing the final versions of the forms. In this form; there are questions such as gender of the student, education of mother and father, mother and father professions, income level of their families, whether the student has a room of his/her own.

Impromptu speaking topics: The topics were identified by the authors by examining the literature and the 4th grade Turkish Teacher Guide Book (B1yıklı \& Öztaş, 2017) and discussing it with classroom teachers and field experts. The suitability and level of the issues were discussed by pre-interviewing seven classroom teachers. Then, four classroom teachers were interviewed separately considering the results obtained from the previous interviews. Finally, field expert's opinion was consulted as a result a total of thirteen speaking topics were identified.

Lessons plans: These outlines were developed by the authors based on the textbook used by the Ministry of National Education for the fourth-grade Turkish languages courses for the school year of 2018-2019 and also, based on the yearly course outlines. During the six-week implementation process, these topics were supported by these texts and activities through educational games.

Impromptu speaking achievement rubric: It was developed by the authors. In the development process of the rubric, the studies on speaking skills were reviewed. Also, the "Learning Gains in Speaking Area" in the fourth-grade Turkish curriculum was examined and taken into account in creating rubric. In addition, the main categories and subcategories of the rubric were developed based on the findings/sources by Dülger (2011), Emiroğlu (2015), Taşer (2009), and Vural (2005). The original form of the rubric included six main and thirty-four subcategories. Following the reviews by a field expert, the rubric was modified to include six main and fifteen subcategories. The speech success rubric consists of the major components of voice, pronunciation, speaking order, vocabulary and body language. This rubric which is a four-point Likert type scale includes four levels of achievement: (1) beginner level, (2) intermediate level, (3) good and (4) very good. The maximum score from this rubric is 60.

Speaking anxiety scale: This scale was developed by Y1ldirım (2015), and it was used in the study with permission by email. The scale is a twenty three-item, threefactor (speaking anxiety during the lesson, out-of-school speaking anxiety, speech anxiety for the immediate environment) and five-point Likert type scale. The Cronbach alpha reliability for the first factor was .0852 , Cronbach alpha for the second factor .866 and the Cronbach alpha reliability for the third factor was .900. This scale, which was originally developed for secondary school students, was presented to the reviews of the field experts in order to decide whether it was suitable for fourth-grade primary school 
students, and it was decided that it was suitable for the fourth-grade level based on the feedback from these experts. Confirmatory factor analysis could not be performed in the study due to the insufficient number of participants. Therefore, the difference between the experimental and control groups on item basis was investigated without taking any total score from the scale.

\section{Data Collection Procedure and Data Analysis}

Before the implementation process, experimental group and control group were informed about the experiment. Also, participants in both groups filled up a "Personal Information Form". "Speaking Anxiety Scale" and "Impromptu Speaking Achievement Rubric" were applied to the experimental and control groups as pretest and posttest. In order to identify the impromptu speaking achievement of the participants, 13 speaking topics were implemented in both experimental and control groups. More specifically, speaking topics were randomly distributed among the participants and it was requested from the participants to give a "two-minute speaking/narration" about the randomly assigned topics. In this phase, participants were allowed for a "30 seconds" thinking time. The Turkish language lessons in the experimental group were taught by one of the authors through the educational games for six weeks and eight hours a week. The control group received the Turkish language courses based on the basic teachinglearning approach stated in the education program of the course by classroom teacher. The procedure of the semi-experimental data collection is given in Table 1:

Table 1

Data Collection Steps

\begin{tabular}{|c|c|c|}
\hline $\begin{array}{l}\text { Steps of the } \\
\text { implementation }\end{array}$ & Groups & Data collection tools \\
\hline First Step & $\begin{array}{l}\text { Experiment } \\
\text { Control }\end{array}$ & $\begin{array}{l}\text { Information on the semi-experimental procedure } \\
\text { Personal Information Form } \\
\text { The Speaking Anxiety Scale (Pretest) } \\
\text { Impromptu Speaking Achievement Rubric (Pretest) }\end{array}$ \\
\hline Second Step & Experiment & Course outline for the first week \\
\hline 1.Week & & Text Name: "Şerife Bacı Documentary" \\
\hline $05-09.11 .2018$ & & Educational Games: Prediction Game-Estimation game \\
\hline Second Step & Experiment & Course outline for the second week \\
\hline 2.Week & & Text Name: "The Man Who Even Repairs the Sun" \\
\hline $12-16.11 .2018$ & & $\begin{array}{l}\text { Educational Games: Prediction game- Puppet Game-Silent Cinema } \\
\text { Game-Story Man Game }\end{array}$ \\
\hline Second Step & Experiment & Course outline for the third week \\
\hline 3.Week & & Text Name: "Mom, I Am Not Disabled" \\
\hline $19-23.11 .2018$ & & $\begin{array}{l}\text { Educational Games: Prediction Game-Ear-to-Ear Game-Empathy } \\
\text { Building Game }\end{array}$ \\
\hline Second Step & Experiment & Course outline for the fourth week \\
\hline 4.Week & & Text Name: "Love is Happiness" \\
\hline 26-30.11.2018 & & $\begin{array}{l}\text { Educational Games: Prediction Game-Fill Your Cart Game-Send } \\
\text { Message to Your Neighbor Game-I Role-Play Game }\end{array}$ \\
\hline
\end{tabular}




\begin{tabular}{|c|c|c|}
\hline Second Step & Experiment & Course outline for the fifth week \\
\hline 5.Week & & Text Name: "Smart Pigeon Matuka" \\
\hline 03-07.12.2018 & & $\begin{array}{l}\text { Educational Games: Prediction Game-Rope Pull Game-Chair } \\
\text { Grabber Game }\end{array}$ \\
\hline Second Step & Experiment & Course outline for the sixth week \\
\hline 6.Week & & Text Name: "Little Inventors" \\
\hline $10-14.12 .2018$ & & $\begin{array}{l}\text { Educational Games: Prediction Game-Time Machine Game-Ball } \\
\text { Winding Game }\end{array}$ \\
\hline \multirow[t]{2}{*}{ Third Step } & Experiment & The Speaking Anxiety Scale (Posttest) \\
\hline & Control & Impromptu Speaking Achievement Rubric (Posttest) \\
\hline
\end{tabular}

Table 1 presents, the names of speaking text topics and educational games per week. For instance, at the sixth week of the semi-experimental research implementation process, "Little Inventors" as the speaking text topic, and "Prediction Game-Time Machine Game-Ball Winding Game" as the educational game were implemented. At this stage of the research, separate instructional/lesson plans were designed. In instructional plans, after the learning outcomes were defined, specific educational games were selected that can improve the speaking skills. Pre-defined texts were processed with the support of educational games given.

Pretest and posttest impromptu speaking skills scores were recorded in the sound recording for later analysis. The sound recordings were listened and evaluated by the researchers according to the Impromptu Speaking Achievement Rubric. Using the Pearson in-class correlation analysis, rater reliability was examined, and the correlation coefficient between the scores given by the raters was found to be .976 . According to this result, a strong relationship between raters can be mentioned. All the data obtained in the research were transferred to the SPSS package program and tested through descriptive and relational tests.

\section{Results}

\section{Descriptive Statistics}

In the study, the standard deviation, mean, skewness and kurtosis values of the scores obtained from the participants in both groups were determined. For the dependent variables (speaking sounds, pronunciation, speaking order, vocabulary, style, body language, and speaking anxiety) in the study, it was determined that the skewness and kurtosis values were between -2.0 and +2.0 in the experimental and control groups, and these values were acceptable in terms of normality (George \& Mallery, 2016, p. 114-115). In this study, due to the low number of samples, histogram and boxplot charts were drawn to visually examine whether the data show normal distribution in each group and it was determined that the data did not show a normal distribution. In order for the distribution to not deviate from the normal distribution, the sample size should be more than 30 or equal (Büyüköztürk, 2014, p. 8). In the Shapiro Wilk test results, some variable values did not show normal distribution; some variable values were found to show normal distribution. Nonparametric methods were used in the study since some of the sub research questions of the study did not show normal distribution and the sample of the study was relatively small $\left(N_{\text {Experiment }}=15\right.$ and $\left.N_{\text {Control }}=13\right)$. 


\section{Findings on Sub-Problems}

Mann-Whitney $U$ tests were conducted to determine whether the pretest scores of the dependent variables in experimental and control groups differ statistically and it was calculated that all variables did not differ significantly between the experimental and control groups at the beginning of the study. However, the tenth item of the Speaking Anxiety Scale is found to have the score of $p=.027$ which was eliminated from the analysis $(p>.05)$. In the research, posttest scores were analyzed in the analyzes since the groups were equal in terms of pretest scores and did not differ significantly.

Table 2

Mann-Whitney U Results of Post-Test on Speaking Sounds

\begin{tabular}{lccccc}
\hline Group & $N$ & Mean rank & Total rank & $U$ & $p$ \\
\hline Experimental & 15 & 17.27 & 259.00 & 56.00 & .049 \\
Control & 13 & 11.31 & 147.00 & & \\
\hline
\end{tabular}

As seen in Table 2, there was a statistically significant difference between the experimental and control groups speaking sounds posttest scores $(U=56, p=.049)$. According to this result, it can be said that the semi-experimental application has a positive effect on the sound in favor of the experimental group.

Table 3

Mann-Whitney U Results of Post-Test on Pronunciation

\begin{tabular}{lccccc}
\hline Group & $N$ & Mean rank & Total rank & $U$ & $p$ \\
\hline Experimental & 15 & 15.47 & 232.00 & 83.00 & .400 \\
Control & 13 & 13.38 & 174.00 & & \\
\hline
\end{tabular}

As seen in Table 3, there was no statistically significant difference between the experimental and control groups pronunciation posttest scores ( $U=83, p>.05)$. According to this result, it can be said that semi-experimental application has no effect on pronunciation.

Table 4

Mann-Whitney U Results of Post-Test on Speaking Order

\begin{tabular}{lccccc}
\hline Group & $N$ & Mean rank & Total rank & $U$ & $p$ \\
\hline Experimental & 15 & 17.40 & 261.00 & 54.00 & .039 \\
Control & 13 & 11.15 & 145.00 & & \\
\hline
\end{tabular}

As seen in Table 4, there was a statistically significant difference between the experimental and control groups speaking order posttest scores ( $U=54, p=.039)$. According to this result, it can be said that quasi-experimental practice has a positive effect on the speaking order in favor of the experimental group. 
Table 5

Mann-Whitney U Results of Post-Test on Vocabulary

\begin{tabular}{lccccc}
\hline Group & $N$ & Mean rank & Total rank & $U$ & $p$ \\
\hline Experimental & 15 & 15.03 & 225.50 & 89.50 & .704 \\
Control & 13 & 13.88 & 180.50 & & \\
\hline
\end{tabular}

As seen in Table 5, no statistically significant difference was found between the vocabulary posttest scores of the experimental and control groups vocabulary posttest scores $(U=89.50, p>.05)$. According to this result, it can be said that semi-experimental application has no effect on vocabulary.

Table 6

Mann-Whitney U Results of Post-Test on Style

\begin{tabular}{lccccc}
\hline Group & $N$ & Mean rank & Total rank & $U$ & $p$ \\
\hline Experimental & 15 & 16.97 & 254.50 & 60.50 & .046 \\
Control & 13 & 11.65 & 151.50 & & \\
\hline
\end{tabular}

As seen in Table 6, there was a statistically significant difference between the experimental and control groups style posttest scores $(U=60.50, p=.046)$. According to this result, it can be said that semi-experimental application has a positive effect on the style in favor of the experimental group.

Table 7

Mann-Whitney U Results of Post-Test on Body Language

\begin{tabular}{lccccc}
\hline Group & $N$ & Mean rank & Total rank & $U$ & $p$ \\
\hline Experimental & 15 & 15.67 & 235.00 & 80.00 & .413 \\
Control & 13 & 13.15 & 171.00 & & \\
\hline
\end{tabular}

As can be seen in Table 7, there was no statistically significant difference between the vocabulary posttest scores of the experimental and control groups body language posttest scores $(U=80, p>.05)$. According to this result, it can be said that semi-experimental application has no effect on body language. 
Table 8

Mann-Whitney U Results of Post-Test on Speaking Anxiety

\begin{tabular}{|c|c|c|c|c|c|c|}
\hline Item & Group & $N$ & Mean rank & Total rank & $U$ & $p$ \\
\hline \multirow{2}{*}{1} & Experimental & 15 & 11.63 & 174.50 & 54.50 & .040 \\
\hline & Control & 13 & 17.81 & 231.50 & & \\
\hline \multirow{2}{*}{2} & Experimental & 15 & 13.07 & 196.00 & 76.00 & .293 \\
\hline & Control & 13 & 16.15 & 210.00 & & \\
\hline \multirow{2}{*}{3} & Experimental & 15 & 12.90 & 193.50 & 73.50 & .239 \\
\hline & Control & 13 & 16.35 & 212.50 & & \\
\hline \multirow{2}{*}{4} & Experimental & 15 & 12.67 & 190.00 & 70.00 & .189 \\
\hline & Control & 13 & 16.62 & 216.00 & & \\
\hline \multirow{2}{*}{5} & Experimental & 15 & 15.70 & 235.50 & 79.50 & .384 \\
\hline & Control & 13 & 13.12 & 170.50 & & \\
\hline \multirow{2}{*}{6} & Experimental & 15 & 14.60 & 219.00 & 96.00 & .942 \\
\hline & Control & 13 & 14.38 & 187.00 & & \\
\hline \multirow{2}{*}{7} & Experimental & 15 & 12.30 & 184.50 & 64.50 & .117 \\
\hline & Control & 13 & 17.04 & 221.50 & & \\
\hline \multirow{2}{*}{8} & Experimental & 15 & 13.70 & 205.50 & 85.50 & .564 \\
\hline & Control & 13 & 15.42 & 200.50 & & \\
\hline \multirow{2}{*}{9} & Experimental & 15 & 14.93 & 224.00 & 91.00 & .751 \\
\hline & Control & 13 & 14.00 & 182.00 & & \\
\hline \multirow{2}{*}{10} & Experimental & 15 & 15.10 & 226.50 & 88.50 & .656 \\
\hline & Control & 13 & 13.81 & 179.50 & & \\
\hline \multirow{2}{*}{11} & Experimental & 15 & 13.60 & 204.00 & 84.00 & .521 \\
\hline & Control & 13 & 15.54 & 202.00 & & \\
\hline \multirow{2}{*}{12} & Experimental & 15 & 12.93 & 194.00 & 74.00 & .268 \\
\hline & Control & 13 & 16.31 & 212.00 & & \\
\hline \multirow{2}{*}{13} & Experimental & 15 & 13.57 & 203.50 & 82.50 & .479 \\
\hline & Control & 13 & 15.58 & 202.50 & & \\
\hline \multirow{2}{*}{14} & Experimental & 15 & 14.53 & 218.00 & 90.00 & .722 \\
\hline & Control & 13 & 14.46 & 188.00 & & \\
\hline \multirow{2}{*}{15} & Experimental & 15 & 15.20 & 228.00 & 85.50 & .571 \\
\hline & Control & 13 & 13.69 & 178.00 & & \\
\hline \multirow{2}{*}{16} & Experimental & 15 & 14.63 & 219.50 & 86.50 & .601 \\
\hline & Control & 13 & 14.35 & 186.50 & & \\
\hline \multirow{2}{*}{17} & Experimental & 15 & 12.40 & 186.00 & 93.00 & .823 \\
\hline & Control & 13 & 16.92 & 220.00 & & \\
\hline
\end{tabular}




\begin{tabular}{ccccccc}
\hline 18 & Experimental & 15 & 12.90 & 193.50 & 81.50 & .354 \\
& Control & 13 & 16.35 & 212.50 & & \\
\hline \multirow{2}{*}{19} & Experimental & 15 & 12.73 & 191.00 & 95.50 & .920 \\
& Control & 13 & 16.54 & 215.00 & & \\
\hline \multirow{2}{*}{20} & Experimental & 15 & 13.97 & 209.50 & 65.50 & .122 \\
& Control & 13 & 15.12 & 196.50 & & \\
\hline \multirow{2}{*}{21} & Experimental & 15 & 11.97 & 179.50 & 89.50 & .685 \\
& Control & 13 & 17.42 & 226.50 & & \\
\hline \multirow{2}{*}{22} & Experimental & 15 & 13.10 & 196.50 & 96.00 & .942 \\
& Control & 13 & 16.12 & 209.50 & & \\
\hline \multirow{2}{*}{23} & Experimental & 15 & 13.77 & 206.50 & 85.50 & .557 \\
& Control & 13 & 15.35 & 199.50 & & \\
\hline
\end{tabular}

In the study, whether there is a significant difference between the experimental and control groups speaking anxiety posttest scores was examined on the basis of the items in the scale. As can be seen in Table 8, only the first item $(U=54.50, p=.040)$ has been identified as a significant differentiation. $(p>.05)$. In other items in the scale, no significant difference was found between the experimental and control group speaking anxiety posttest scores. The reason for this differentiation observed in only one article was interpreted that it may not be caused by semi-experimental application. Therefore, it can be argued that the semi-experimental practice does not have any effect on speaking anxiety.

\section{Discussion and Conclusion}

The findings obtained in this study aiming to determine the effects of the educational games on the impromptu speaking skills and speaking anxiety of fourthgrade elementary school students were discussed based on the previous findings. At the beginning of the research, no statistically significant difference was found between the students in the experimental and control groups in terms of their impromptu speaking skill scores (speaking sounds, pronunciation, speaking order, vocabulary, style and body language). At the end of the research, it was observed that the dependent variable of speaking sounds consisting of the dimensions of audibility and significance significantly differed in favor of the experimental group. Therefore, it is safe to argue that the educational games used in courses have positive effects for the speaking sounds which are part of the impromptu speaking skills. In the study conducted by Sargin (2006), it was found that the volume of the voice of the majority of students was at an appropriate level. In the meaningfulness dimension of the speaking sounds there are concepts such as rhythm, fluency, uniformity, emphasis, intonation and appropriate pause. Dewi et al. (2017) analysed the effects of communicative games on speaking skills. They found that such games positively affected the fluency of students' speaking. In this context, the research findings support each other.

The findings of the study suggest that pronunciation which refers to sound reduction was not better for the experiment group. Yeşiltepe Sağlam (2010) found that 
students cannot pronounce the $/ r /$ voice in the suffix "-yor", that they cannot pronounce the vowels in the words such as "ölcek (die), ordaki (there) and üniverste (university)" and that they experience sound erosion for the sounds $/ h /$ and $/ \breve{g} /$ in the words, including "meşur instead of meşhur (famous) and ööretmen instead of öğretmen (teacher)". In the current study it is also found that the participants did not manage to pronounce the speaking sound $/ r /$ in the suffix "-yor" or in the words like "bir (one)" and that they produced the following words "gitcek instead of gidecek (he will go) and gelcek instead of gelecek (he will come)" and that they used the form of "öortmenim" instead of "öğretmenim (my teacher)". Therefore, the present findings are consistent with the previous ones.

The findings of the study also indicate that the speaking order or speaking dynamics which refers to the expression of topics and views, refinement (giving examples and description etc.) and the use of tense is much better for the experiment group. Yeşiltepe Sağlam (2010) found that the speaking by the students is mostly in line with the topics given but they cannot develop plans for their speaking and provide the events and the related information in an unplanned way.

According to the conclusion reached in this study, it can be said that the students' ability to give examples, description and detailing improved during the speaking as a result of the educational games used in the experiment group. It is stated by Yeşiltepe Sağlam (2010) that students do not use ways of developing thought in their speaking (such as defining, describing, sampling, comparing, showing witness, analogy, and making use of numerical data). Yüceer (2014) found that the students had fair levels of the definition, sampling and detailing. In the study conducted by Sargin (2006), it was concluded that students could not develop rich ways of thinking. In regard to this study, it can be stated that students' time management skills were developed during the impromptu speaking as a result of the educational games. The students made speaking for two minutes. It can be stated that many students could not complete two minutes during the implementation, and also several students exceeded two minutes while making their speaking. In a similar study by Yeşiltepe Sağlam (2010) the students were given three minutes to make a speaking, but they cannot fully use the time given.

Vocabulary, which is composed of the use of proverb and idiom, special nouns, expressions and the use of pronoun "şey (stuff)" does not show a significant difference in favor of the experimental group. Research suggests that the students do not employ proverbs in their speaking, but use some idiom while making a speaking. Yeşiltepe Sağlam (2010) concludes that impromptu speaking does not contain any use of proverbs and idioms. In the study by Sargin (2006), it is found that the speaking of the students lacked the proverbs, aphorism, and idioms etc. According to the results of the study conducted by Emiroğlu (2015), it can be said that the proverbs are used less, and the idioms are used a little more than the proverbs. In this study, it can be said that students mostly use the number "one" as the number expression. Again, in the study of Emiroğlu (2015), the most frequently used first five number expressions that students use are determined as "one, two, first, four and third". The use of the pronoun "şey" is accepted as an evidence of not finding the proper word. Some students employed the pronoun "stuff". In the study by Emiroğlu (2015) it is found that the students use words such as "something, so, another, that is, behold, for example, etc.” Yeşiltepe Sağlam (2010) also 
concluded that the students used some words such as "stuff, well, how can I tell, so" when they could not find the right words while expressing their ideas.

The dependent variable of style, which is defined as sound, speed, selfconfidence, repeating words, prolonging the end of words, and making sounds like "eee / 1111 / aaa / himmm" in pauses, has been found to differ significantly in favor of the experimental group. When the style is analysed in terms of speaking sounds the excitement of the students and the control of voice were taken into consideration. In this study, it was seen that the voice of several students trembled for a short time. In the study conducted by Sargin (2006), it was observed that the students were excited while talking and $71 \%$ of them had shaking voices while making a speaking. When the style is analysed in terms of speaking rate it is found that the students talked fast ending their speaking immediately. When the style is evaluated in terms of self-confidence, it can be said that most of the students in the study are confident while making speaking. Hwang Hwang, Shih, Ma, Shadiev, and Chen (2016) found that a mobile system containing game-based activities supported the students in producing meaningful sentences and their speaking with confidence. When style is analysed in terms of repetition of the words, in this study it is found that most of the students repeat the words during their speaking. Sargin (2006) stated that $44 \%$ of students repeat words or sentences. When the style is evaluated in terms of extending the end of the words, it can be said that most of the students do not make any such extension while speaking. In the Sargin's (2006) study, it was concluded that $98 \%$ of the students did not lengthen the voices unnecessarily while speaking. When the style is evaluated in terms of producing meaningless sounds like "eee / 1111 / aaa / hımmm" in pauses, some of the students are found to make such parasitic sounds in the pauses. According to the conclusions reached by Yeşiltepe Sağlam (2010) regarding the parasitic voices analyzed under the title of fluency, it was found that the students made meaningless voices such as "11, eee, aaa" in order to gain time to think.

The dependent variable of the body language, which is composed of posture, gesture, mimic and eye contact dimensions, did not show a significant improvement in favor of the experimental group. In the study, most of the students shake in place for some or all of the speaking time. It can also be stated that some of the students are standing still while some of them are not. It can be said that very few of these students confidently stood in a proper place while making a speaking. In the study by Sargin (2006) it was found that in regard to expressing self-confidence with the stance $62 \%$ of 207 students were identified not to feel self-confident based on their stances during speaking. In the study by Yeşiltepe Sağlam (2010), students' body language movements are partially measured and found that sometimes they do not control their body movements; however, it is stated that this is not at a very disturbing level. In this study, most of the students did not use their hands and arms during their speaking. It can be said that students who used their hands and arms while talking did not manage to use them at a sufficient level. It can also be stated that most students make movements with their hands and arms indicating that they are embarrassed or bored, while some of them hold their hands behind or in front, or they play with their jersey by putting them on their side or open and close their fingers. On the other hand, the facial expressions of the students were slightly better than their gestures. However, it should be added that this was not sufficient. In the study of Sargin (2006), 65\% of 207 students made unnecessary 
movements and did not know where to put their hands and how to hold their hands while speaking. In this study, most of the students are found to have eye contact with the audience; however, it can be said that they cannot use it effectively. Some students can be said to look down on the floor while speaking with their heads forward. In the study carried out by Sargin (2006), it was concluded that $54 \%$ of the students in general had eye contact with the audience. Yüceer (2014) found that in regard to eye contact the participants had a fair level of success.

At the end of the study, it was observed that the dependent variable of speaking anxiety consisting of three dimensions, namely speaking anxiety when talking to the others, out of school speaking anxiety and speaking anxiety during the lesson, did not show a significant difference in favor of the experimental group. Therefore, it can be stated that the educational games used in the study do not have a significant positive effect on the participants' speaking anxiety. The state of anxiety, which is a term belonging to the affective domain, was not affected by this six-week practice consisting of educational games. It can be due to the fact that there was a short implementation period and that the anxiety scale used was originally developed for the students at the middle school level.

In the study conducted by Tüzemen (2016), it was concluded that the academic contradiction technique used for twelve weeks was more effective than the activities carried out within the framework of the Turkish Teaching Program in reducing the students' speaking anxiety. In the study conducted by Bulut (2015), it was concluded that the teaching of the Speaking Education course with the micro teaching technique for 14 weeks reduced the speaking anxiety of the pre-service Turkish language teachers compared to the traditional method. The reason why the findings of this study and other studies are not similar is that the independent variables are different and the implementation durations are different. Based on the results of the study the following suggestions are developed:

- In the study, it is concluded that educational games improve students' speaking skills. In this context, teachers are recommended to include educational games in their lessons and to use the impromptu speaking techniques.

- During the implementation process in the study, it was observed that some students could not use non-verbal communication elements effectively. In future studies activities to improve these skills can be designed.

- The participants of the study are just twenty-eight students. In order to have much more generalizable findings the number of participants can be more.

- Future studies may employ the qualitative data collected from observations and interviews.

- In this research, the effects of educational games on students' speaking skills were examined. These effects can be analysed in relation to other language skills in future studies.

\section{Statement of Responsibility}

Huri Asan; conceptualization, methodology, data collection, validation, investigation, data curation, writing - original draft, writing - review \& editing. Zuhal Çeliktürk-Sezgin; conceptualization, design of research process, methodology, validation, investigation, data curation, writing-reviewing \& editing, and supervision. 


\section{References}

Bailey, K. M. (2005). Practical English language teaching: Speaking. New York: McGraw-Hill.

Baştürk, R. (2011). Deneme modelleri. A. Tanrioğen (Ed.), Bilimsel araştırma yöntemleri içinde (s. 31-53). (2. Baskı). Ankara: Anı Yayıncılık.

Bıyıkı1, H., \& Öztaş, Y. (2017). İlkokul 4. sınıf Türkçe öğretmen kılavuz kitabı. Ankara: Doku Yayıncilik.

Bulut, K. (2015). Mikro öğretim tekniğinin Türkçe öğretmen adaylarının konuşma beceri ve kaygllarına etkisi (Unpublished doctoral dissertation). Gazi University.

Büyüköztürk, Ş. (2014). Sosyal bilimler için veri analizi el kitabı. Ankara: Pegem Akademi Yayınları.

Bygate, M. (1987). Speaking. Oxford University Press.

Cheng, Y. S. (2004). A measure of second language writing anxiety: Scale development and preliminary validation. Journal of Second Language Writing, 13(4), 313-335.

Çeliktürk, Z., \& Yamaç, A. (2015). İlkokul ve ortaokul öğrencileri için okuma kaygısı ölçeğinin geliştirilmesi: Geçerlik ve güvenirlik çalışması. Elementary Education Online, 14(1), 97-107.

Daly, J. A., \& Miller, M. D. (1975). The empirical development of an instrument of writing apprehension. Research in the Teaching of English, 9, 242-249.

Demir, T., \& Melanlığlu, D. (2014). Ortaokul öğrencileri için konuşma kaygısı ölçeği: geçerlik ve güvenirlik çalışması. Ankara University Journal of Faculty of Educational Sciences, 47(1), 103-124.

Demirel, Ö. (2011). Öğretme sanatı. Ankara: Pegem Akademi Yayınları.

Dewi, R. S., Kultsum, U., \& Armadi, A. (2017). Using communicative games in improving students' speaking skills. English Language Teaching, 10(1), 63-71.

Dülger, M. (2011). Konuşma becerisinin ilköğretim öğrencilerine öğretimi üzerine bir inceleme (Unpublished master's thesis). Dokuz Eylül University.

Emiroğlu, S. (2015). Öğrencilerin hazırlıksız konuşmada kullandığı farklı kelime sayısının tespiti ve incelenmesi. Tarih Okulu Dergisi, 8(23), 19-40.

Gedik, M. (2012). Ortaokul ikinci sinıf ögrrencilerinin temel dil becerilerinin geliştirilmesinde ĕgitsel oyunların başarı ve kalıcılı̆̆a etkileri (Unpublished doctoral dissertation). Atatürk University.

George, D., \& Mallery, P. (2016). IBM SPSS Statistics 26 step by step: A simple guide and reference. (14 ${ }^{\text {th }}$ Press). New York: Routledge.

Hwang, W. Y., Shih, T. K., Ma, Z. H., Shadiev, R., \& Chen, S. Y. (2016). Evaluating listening and speaking skills in a mobile game-based learning environment with situational contexts. Computer Assisted Language Learning, 29(4), 639-657. http://dx.doi.org/10.1080/09588221.2015.1016438

Karasar, N. (2007). Bilimsel araştırma yöntemi. (17. Baskı). Ankara: Nobel Yayınları.

Keşaplı, G., \& Çifci, M. (2017). Ortaokul öğrencilerinin konuşma kaygısı (Speech anxiety of elementary school students). The Journal of Academic Social Science Studies, 54, 463-484. 
Pekrun, R., Goetz, T., Perry, R. P., Kramer, K., Hochstadt, M., \& Molfenter, S. (2004). Beyond test anxiety: Development and validation of the test emotions questionnaire (TEQ). Anxiety, Stress, and Coping, 17, 287-316.

Sargın, M. (2006). Illköğretim öğrencilerinin konuşma becerilerinin değerlendirilmesi Muğla ili örneğinde (Unpublished master's thesis). Muğla University.

Sevim, O., \& Gedik, M. (2014). Ortaöğretim öğrencilerinin konuşma kaygılarının çeşitli değişkenler açısından incelenmesi. A. Ü. Türkiyat Araştırmaları Enstitüsü Dergisi, 52, 379-393.

Taşer, S. (2009). Konuşma eğitimi. İstanbul: Pegasus Yayınları.

Topçuoğlu Ünal, F., \& Degeç, H. (2012). Öğretmen görüşlerine göre konuşma eğitiminde karşılaşılan sorunlar. JASSS, 5(7), 735-750.

Tüzemen, T. (2016). Akademik çelişki tekniğinin 6. sınıf öğrencilerinin konuşma becerilerine ve konuşma kaygılarına etkisi (Unpublished master's thesis). Yüzüncü Y1l University.

Ur, P. (1996). A course in language teaching: practice and theory. Cambridge: Cambridge University Press.

Ünalan, Ş. (2001). Türkçe öğretimi. (Geliştirilmiş 2. Baskı). Ankara: Nobel Yayınları.

Varan, S. (2017). Illkokul 4. sınıf ögrrencilerinin zihinsel sözlüğünü geliştirmede eğitsel oyunların etkisi (Unpublished master's thesis). Bartın University.

Vural, B. (2005). Doğru ve güzel konuşma. İstanbul: Hayat Yayınları.

Wigfield, A., \& Eccles, J. S. (1989). Test anxiety in elementary and secondary school students. Educational Psychologist, $\quad 24(2), \quad$ 159-183. https://doi.org/10.1207/s15326985ep2402_3

Wigfield, A., \& Meece, J. L. (1988). Math anxiety in elementary and secondary school students. Journal of Educational Psychology, 80(2), 210-216. https://doi.org/10.1037/0022-0663.80.2.210

Woodrow, L. (2006). Anxiety and speaking English as a second language. RELC Journal, 37(3), 308-328.

Yeşiltepe Sağlam, Ö. (2010). Yedinci sınıf öğrencilerinin hazırlıksız konuşma becerileri üzerine bir araştırma (Unpublished master's thesis). Gazi University.

Yıldırım, G. (2015). Ortaokul öğrencilerinin konuşma kaygısı (Unpublished master's thesis). Uşak University.

Yüceer, D. (2014). Türkçe öğretmenliği birinci sınıf öğrencilerinin hazırlıksız konuşma becerileri üzerine bir araştırma (Unpublished master's thesis). Gazi University.

This is an Open Access article distributed under the terms of the Creative CommonsAttributionNonCommercial-ShareAlike 4.0 International (CC BY-NC-SA 4.0). For further information, you can refer to https://creativecommons.org/licenses/by-nc-sa/4.0/ 